THE JOURNAL OF PHILOSOPHICAL ECONOMICS:

REFLECTIONS ON ECONOMIC AND SOCIAL ISSUES

Volume XIV Issues 1-2

Spring-Autumn 2021

ISSN: $1843-2298$

EISSN: $1844-8208$

Publication date:

20 November 2021

Paper format: $16.5 \times 23.5 \mathrm{~cm}$

Copyright note:

Authors retain unrestricted copyright and all publishing rights in compliance with the Creative Commons license CC BY-NC-SA.
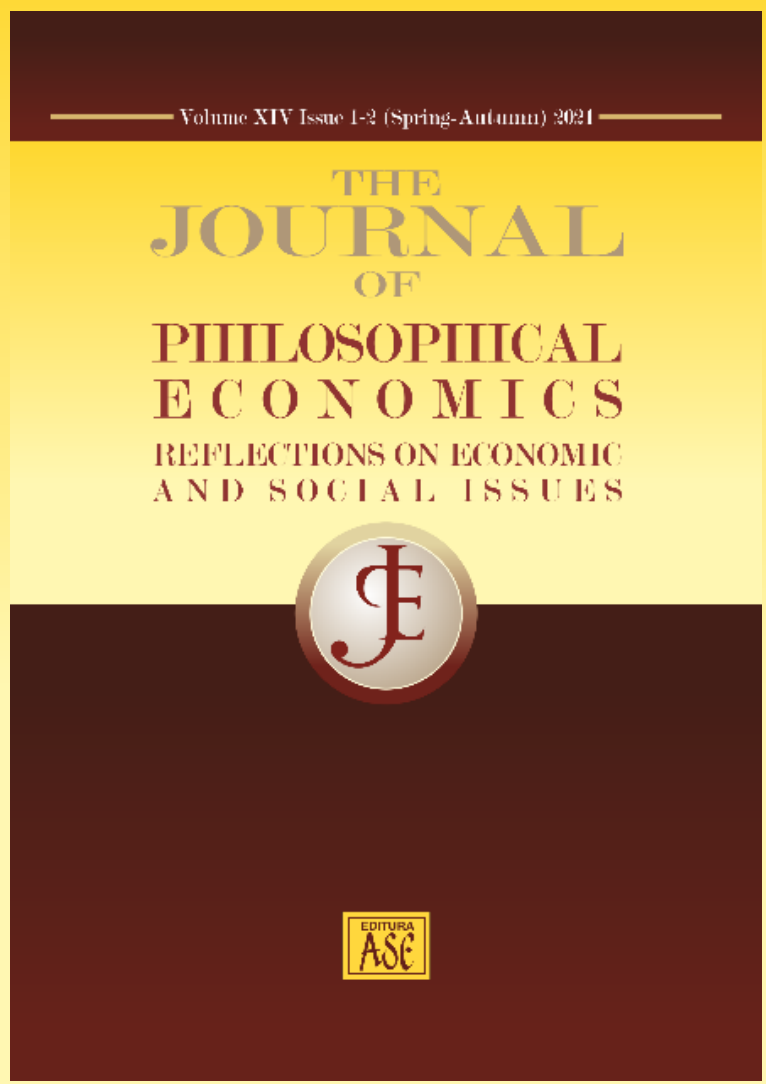

How the attitude of Chicago economics towards philosophy changed over time: an essay on what role some historical methods should play in practicing the philosophy of economics

Peter Galbács 


\section{How the attitude of Chicago economics towards philosophy changed over time: an essay on what role some historical methods should play in practicing the philosophy of economics}

\section{Peter Galbács}

This essay sets Chicago economics as an example for how today's economics belittles the importance of explicit philosophical studies. Given that economists keep their methodological stances rather implicit, it is argued that the correct reconstruction of these hidden methodological foundations might require philosophers to turn to unpublished materials.

Economics as a social science investigates the consequences and the determining factors of individual and social actions involving scarce resources. To this, any considerations regarding the alternative ways of fulfilling this primary purpose are inevitably subordinated. Economic methodology is thus a second-order activity that is carried out by professionals to find answers to specific questions about the nuts and bolts of economic enquiry (Mäki 2021). Normally, thinking about the methodological foundations of economics and the philosophical aspects of our modelling and theorizing routines is a part of our everyday work (Weintraub 1989). With time, however, the place that such meta-scientific considerations occupy in our discipline has significantly changed. A century ago, not to mention the classic times of Adam Smith or David Hume, it was quite common for one to regard economics and philosophy as a close-knit unity. Then economics was a discipline that was not deprived of its explicit philosophical foundations, doing economics was thus impossible without indulging in farreaching philosophical reflections. Economists were also philosophers. Soon thereafter economics became a more technical field of study, and economists lost interest in systematic philosophical studies (Vromen 2021). Like any other branch of science, economics was still in need of a philosophical foundation the Received: 17 July 2021 
Galbács Peter (2021), How the attitude of Chicago economics towards philosophy

changed over time: an essay on what role some historical methods should play

in practicing the philosophy of economics, The Journal of Philosophical Economics:

Reflections on Economic and Social Issues, XIV (1-2), 177-185

construction of which forced economists to step outside the comfort zone of setting up and estimating equations. This basis, however, became increasingly implicit, insufficiently elaborated or even contradictory as economists became amateur in taking the exterior position of philosophical self-reflection. Simultaneously, the novel subdiscipline of the methodology and philosophy of economics was given birth by thinkers like philosophically biased economists and philosophers with a special interest in economics and the social sciences to scrutinize the philosophical grounds of economics with a systematic approach that practicing economists were no longer capable of.

This summary is no more than a bird's eye review of a story that can be filled with events in many distinct cases, though. In the case of Chicago economics, a comprehensive scientific and educational program that played a major role in defining today's 'good economics' even far beyond the boundaries of the United States (Emmett 2007; 2009; 2010; Van Horn, Mirowski, \& Stapleford 2011), we can see the same events - separating economics from philosophy by narrowing the focus of economic analysis and minimizing the scope of philosophical considerations to an inevitable and informal minimum. Relocating the story of the philosophy of economics from the abstract back into the concrete by telling it in the Chicago setting, the purpose of the present essay, however, offers a perspective the implications of which reach beyond the history of science. As we shall see, the way Chicago economics has been related to its own philosophical foundations warns us, historians and methodologists, to move beyond the realm of published texts. Given that dwelling upon the underlying philosophical and methodological views has been declared inferior to doing economics narrowly conceived, what we normally can find in published texts is only the visible corollaries of the subsurface layers of the enormous iceberg of philosophically and methodologically oriented economic thinking. The conclusion emerges that reconstructing or criticizing the methodological foundations of theories, the normal activities of a methodologist, presuppose some historical methods like working with unpublished notes, drafts, and letters to complement what can be found in published texts. Discussing the relationship between Chicago economics and philosophy below is thus not an end in itself, but a way of drawing attention to why the application of historical methods in the philosophy of economics is so important. 
Galbács Peter (2021), How the attitude of Chicago economics towards philosophy

changed over time: an essay on what role some historical methods should play

in practicing the philosophy of economics, The Journal of Philosophical Economics:

Reflections on Economic and Social Issues, XIV (1-2), 177-185

To begin with, Frank Knight stands out as an ideal type of the philosopher economist. He played a major role in placing the Chicago school of economics on a massive price theoretic foundation - in this sense he was a forerunner of the post-war imperialistic developments, when Gary Becker extended the scope of neoclassical economics to a wide range of individual and social actions. Knight, however, was cautious not to place too much emphasis upon the adequacy of neoclassical price theory in explaining human behavior. For him, man was a social and cultural creature (Knight 1948), so he did not regard the questions of economizing on scarce resources as problems of a genuinely social science. To find the optimal allocation of a resource is an individual problem (McKinney 1975), it is thus no wonder that neoclassical economics deprived man of his social environment - as a result, however, the homo oeconomicus faced no social issues. As Knight argued, resource allocation is a question of simple instrumental rationality when market participants consider how to achieve given ends. By contrast, he continued, ends are of social character, so rational market agents do not take ends as pre-set but actively shape them in social discussions (Knight 1925; Emmett 1994). If ends are given, economics comes down to the technical questions of constrained optimization, but if not, economists do not need to refrain from addressing the ethical questions of social good and happiness, and economics remains open to philosophical discussions. In the light of what we think about economics today, Knight is better described not as an economist but a social philosopher. When it came to finding an adequate place for neoclassical economics or mulling over social goals, or whether preferences can really be treated as the ultimate primitives of economics (Emmett 2006), Knight entered fields what in modern parlance are labelled as economic methodology and the philosophy of economics.

By the post-war years, Knight's influence had faded away, and Friedman had become the 'strong man' at the Chicago department. His rising to dominance launched a new phase in the relationship of economics to philosophy. First, he limited the scope of economic studies to constrained optimization. For Friedman (1962, p. 1), '[a]n economic problem exists whenever scarce means are used to satisfy alternative ends. If the means are not scarce, there is no problem at all; there is Nirvana.' Later, Becker (1971) and Stigler (1976) extended this approach to a wide range of human actions, where human decisions became economic 
Galbács Peter (2021), How the attitude of Chicago economics towards philosophy

changed over time: an essay on what role some historical methods should play

in practicing the philosophy of economics, The Journal of Philosophical Economics:

Reflections on Economic and Social Issues, XIV (1-2), 177-185

decisions on the optimal allocation of scarce resources of whatever nature between alternative ends of whatever nature. By claiming so, Friedman thus cancelled the philosophical questions addressed by Knight from the radar of economic science. Economists, just like anyone else, are free to engage in philosophical discussions over goals, but to do so, they need to move outside economics. Becoming increasingly technical and becoming increasingly $a^{-}$ philosophical were two sides of the same coin of the evolution of Chicago economics.

And second, Friedman was rather hostile to explicit methodological studies, so normally he buried methodological discussions under the visible layers of doing economics (Galbács 2020, pp. 115-127). He owns only one such a paper - his famous positivist essay (Friedman 1953). The intensity of the reactions it stirred up kept Friedman away from the controversies. Looking back on those years, he explained his reluctance to defend his methodological views by citing Marshall's passivity, and by disparaging methodologically oriented works (Hammond 1988). On the one hand, perhaps as a manifestation of his general admiration to Marshall, he set Marshall as an example for an economist who placed too much emphasis on fronting up in the scrums over theory and methodology. On the other hand, and this is more relevant to our case in point, he expressed his view that doing economics should always take priority over figuring out how economics is supposed to be done. Theories and their alleged underlying methodologies often diverge, so, as he thought, doing economics does not presuppose well-formed and explicit methodological views. Consequently, dedicated methodological studies may be interesting for rookies at best, who joining the scientific community may find it beneficial to collect their methodological thoughts - but seriously for themselves and not for publication. And if methodology is no more than an informal background of theorizing, one does not need systematic reading in methodology and philosophy. As a standard, by saying so, Friedman suggested economists be amateur and naïve philosophers. This is the path Friedman also took - as both a writer and reader he was terrible at philosophy (Forder 2019).

The scene was thus set for Robert E. Lucas. As a theorist, threading in Becker and Stigler's footsteps, he completed the extension of the basic price-theoretic 
Galbács Peter (2021), How the attitude of Chicago economics towards philosophy

changed over time: an essay on what role some historical methods should play

in practicing the philosophy of economics, The Journal of Philosophical Economics:

Reflections on Economic and Social Issues, XIV (1-2), 177-185

framework to the theory of large-scale fluctuations. As a methodologist, however, he followed Friedman in keeping his explicit methodological studies to a minimum. He devoted only two published papers to methodological considerations (Lucas 1977; 1980) as fruits of his professorship in macroeconomics at the University of Chicago. There is no textual evidence that Lucas ever regarded Friedman's obstinacy in staying away from methodology as a model - but still, it is a striking feature of Lucas's lifework that, just like Friedman, he treated explicit methodological studies only as preparations for theorizing. As a result, his unpublished drafts and letters abound in methodological considerations which the published works only briefly refer to at best. Quite typically, in his published works one can find only brief remarks about why he believed macroeconomics needed microfoundations, or what requirements he set against the causal performance of models or the realism, whatever it meant to him, of assumptions. He did economics while taking for granted such underlying ideas he elaborated as a first step. This is the reason why the recent Lucas literature (De Vroey 2016; Galbács 2020) made efforts to parlay these scattered notes into a systematic methodological portrayal of Lucas.

In Lucas's case, there is thus a sharp contrast between published and unpublished works in terms of methodology that has some implications regarding the methods of the philosophy of economics. As Epstein (2015) argues, the way we aspire knowledge determines what we can know and whether we know something at all. Economic methodology, or the philosophy of economics treated in a narrow sense (Boland 2016), is thus inseparable from building theories. The theoretical content cannot adequately be reconstructed without taking the methodological foundations into account. Based on the methodological foundations, distinct meanings can be input into statistical correlations. So, say, what Friedman conceived of the connection between the money supply and the dynamics of nominal income on the one hand, and how changes in nominal income can be separated into real economic fluctuations and inflation on the other hand cannot properly be understood as deprived of the methodological background. It is his methodological stance that ordains whether the assumed connection is like the correlation between the number of storks and new-born babies (Matthews 2000), or it is a firm causal relationship pointing from the money stock towards the level of economic activity. 
Galbács Peter (2021), How the attitude of Chicago economics towards philosophy

changed over time: an essay on what role some historical methods should play

in practicing the philosophy of economics, The Journal of Philosophical Economics:

Reflections on Economic and Social Issues, XIV (1-2), 177-185

However, as we have seen above, it is quite a general trend for economists to regard methodological considerations as of second-order relevance and hence to downplay their importance in publication. Here lies a crucial problem for the philosophy of economics. Given that methodological studies have a historical interest in the reconstruction and understanding of past practices (Mäki 1994), some caution is needed when selecting the textual basis for analyses. Sometimes a carefully set research question may simplify the problem - if an investigation is directed towards the methodological stance that the published text of Friedman's positivist study contains, the need for browsing the Milton Friedman papers does not seem to arise. In cases, however, where there is a large body of textual evidence left unpublished (the Lucas archival collection is a prominent example), it is uncertain whether Nelson's (2020, pp. ix-x) view that there is no need to look beyond the corpus of publications is valid. As Nelson argues, a text should never be analyzed in itself - this is the reason why he discredits philosophical studies for grabbing the positivist methodology out of the textual context. But what are the boundaries of the context he cites? If no text is standalone as Nelson believes, so there is a principled reason for paying attention to the context, what principled reason is for disregarding the unpublished background materials? Hermeneutics has an answer to this dilemma (Galbács 2020, pp. 338-357). One can never know in advance if a textual unit, be it a paragraph of related published work or an unpublished draft, adds to the meaning of a text or set of texts under scrutiny.

As meaning unfolds itself while the embedding text is being read, the wisest thing one can do is not to stop the process by constraining the textual basis of analysis. Arguments in favor of covering unpublished materials as well is a peculiarity history of economic thought and philosophy of economics have in common, even if it is only the former of the two that has already given way to this line of research. Today it is not uncommon for historians to turn to archives. Especially when understood in a broad sense, the philosophy of economics has a distinct area of study that in most cases clearly distinguishes it from the history of economic thought. There are some overlapped territories, though. As we have seen, doing methodology is a part of doing economics, so the history of economic thought inherently becomes a history of economic methodology. As an historical perspective is anything but alien to the philosophy of economics, philosophers of 
Galbács Peter (2021), How the attitude of Chicago economics towards philosophy changed over time: an essay on what role some historical methods should play in practicing the philosophy of economics, The Journal of Philosophical Economics: Reflections on Economic and Social Issues, XIV (1-2), 177-185

economics might want to find research methodologies that facilitate deeper understanding. Incorporating historical methods into practicing the philosophy of economics is not about identity - there is no danger that philosophy is to merge into historical studies. Rather, it is about commitment. Are we determined enough to go deep in archives in search of more complete readings? I believe we should - taking this path may yield a more reliable and sensitive toolkit for the philosophy of economics.

\section{References}

Becker, G. S. (1971), Economic Theory, New York: Alfred A. Knopf.

Boland, L. A. (2016), 'Philosophy of economics versus methodology of economics', Studia Metodologiczne, 36 (1), 17-26.

De Vroey, M. (2016), A History of Macroeconomics from Keynes to Lucas and Beyond, Cambridge: Cambridge University Press.

Emmett, R. B. (1994), 'Frank Knight. Economics versus religion', in Ross Emmett (ed), Economics and Religion. Are they distinct?, Boston: Kluwer, pp. 103-120.

Emmett, R. B. (2006), 'De Gustibus Est Disputandum. Frank H. Knight's reply to George Stigler and Gary Becker's 'De Gustibus Non Est Disputandum' with an introductory essay', Journal of Economic Methodology, 13 (1), 97-111.

Emmett, R. B. (2007), 'Oral history and the historical reconstruction of Chicago economics', History of Political Economy, 39 (S1), 172-192.

Emmett, R. B. (2009), Frank Knight and the Chicago School in American Economics, Abingdon: Routledge.

Emmett, R. B. (ed) (2010), The Elgar Companion to the Chicago School of Economics, Cheltenham: Edward Elgar.

Epstein, B. (2015), The Ant Trap, Oxford: Oxford University Press.

Forder, J. (2019), Milton Friedman, London: Palgrave Macmillan. 
Galbács Peter (2021), How the attitude of Chicago economics towards philosophy changed over time: an essay on what role some historical methods should play in practicing the philosophy of economics, The Journal of Philosophical Economics: Reflections on Economic and Social Issues, XIV (1-2), 177-185

Friedman, M. (1953), 'The methodology of positive economics', in Milton Friedman (ed), Essays in Positive Economics, Chicago: The University of Chicago Press, pp. 3-43.

Friedman, M. (1962), Price Theory, Chicago: Aldine.

Galbács, P. (2020), The Friedman-Lucas Transition in Macroeconomics. A Structuralist Approach. Cambridge, MA: Elsevier Science - Academic Press.

Hammond, J. D. (1988), 'An interview with Milton Friedman on methodology', in Robert Leeson and Charles G. Palm (eds), The Collected Works of Milton Friedman, Stanford: Hoover Institution.

Knight, F. H. (1925), 'Economic psychology and the value problem', The Quarterly Journal of Economics, 39 (3), 372-409.

Knight, F. H. (1948), 'Free society. Its basic nature and problem', The Philosophical Review, 57 (1), 39-58.

Lucas, R. E. (1977), 'Understanding business cycles', Carnegie-Rochester Conference Series on Public Policy, 5, 7-29.

Lucas, R. E. (1980), 'Methods and problems in business cycle theory', Journal of Money, Credit and Banking, 12 (4), 696-715.

Mäki, U. (1994), 'Methodology might matter, but Weintraub's meta-methodology Shouldn't', Journal of Economic Methodology, 1 (2), 215-231.

Mäki, U. (2021), 'The Field. Tasks, pasts, futures.', Journal of Economic Methodology, 28 (1), 3-13.

Matthews, R. (2000), 'Storks deliver babies ( $\mathrm{p}=0.008)$ ', Teaching Statistics, 22 (2), 36-38.

McKinney, J. (1975), 'Frank H. Knight and Chicago libertarianism', Journal of Economic Issues, 9 (4), 777-799.

Nelson, E. (2020), Milton Friedman and Economic Debate in the United States, 1932-1972 (Vol. 1), Chicago: The University of Chicago Press.

Stigler, G. J. (1976), 'The successes and failures of Professor Smith', Journal of Political Economy, 84 (6), 1199-1213. 
Galbács Peter (2021), How the attitude of Chicago economics towards philosophy changed over time: an essay on what role some historical methods should play in practicing the philosophy of economics, The Journal of Philosophical Economics: Reflections on Economic and Social Issues, XIV (1-2), 177-185

Van Horn, R., Mirowski, P., Stapleford, T. A. (eds.) (2011), Building Chicago Economics. New Perspectives on the History of America's Most Powerful Economics Program, Cambridge: Cambridge University Press.

Vromen, J. (2021), 'What are we up to?', Journal of Economic Methodology, 28 (1), 23-31.

Weintraub, E. R. (1989), 'Methodology doesn't matter, but the history of thought might', The Scandinavian Journal of Economics, 91 (2), 477-493.

Peter Galbács is associate professor of economics, Budapest Business School (Hungary), and 'Bolyai' distinguished research professor of the Hungarian Academy of Sciences (pgalbacs@asu.edu). 